\title{
Association of HDL cholesterol and triglycerides with mortality in patients with heart failure
}

\author{
H.F.G. Freitas, E.A. Barbosa, F.H.F.P. Rosa, A.C.P. Lima and A.J. Mansur \\ Instituto do Coração, Faculdade de Medicina, Universidade de São Paulo, São Paulo, SP, Brasil \\ Correspondence to: H.F.G. Freitas, InCor, FM, USP, Av. Dr. Eneas C. Aguiar, 44, 05403-900 São Paulo, \\ SP, Brasil \\ Fax: +55-11-3082-2354. E-mail: dclfreitas@incor.usp.br
}

\begin{abstract}
It has been demonstrated that there is an association between serum lipoproteins and survival rate in patients with ischemic cardiomyopathy, as well as in patients with non-ischemic causes of heart failure. We tested the hypothesis of an association between serum lipoprotein levels and prognosis in a cohort of outpatients with heart failure, including Chagas' heart disease. The lipid profile of 833 outpatients with heart failure in functional classes III and IV of the New York Heart Association, with a mean age of $46.9 \pm 10.6$ years, $655(78.6 \%)$ men and $178(21.4 \%)$ women, was studied from April 1991 to June 2003. The survival rate was estimated by the Kaplan-Meyer's method and the Cox proportional hazards models. Etiology of heart failure was ischemic cardiomyopathy in $171(21 \%)$ patients, Chagas' heart disease in $144(17 \%)$, hypertensive cardiomyopathy in 136 (16\%), and other etiologies in 83 (10\%). In 299 (36\%) patients, heart failure was ascribed to idiopathic dilated cardiomyopathy. Variables significantly associated with mortality were age (hazard ratio, $\mathrm{HR}=1.02 ; 95 \% \mathrm{Cl}=1.01-1.03 ; \mathrm{P}=0.0074)$, male gender $(\mathrm{HR}=$ $1.77 ; 95 \% \mathrm{Cl}=1.2-2.62 ; \mathrm{P}=0.004)$, idiopathic dilated cardiomyopathy $(\mathrm{HR}=1.81 ; 95 \% \mathrm{Cl}=1.16-2.82 ; \mathrm{P}=0.0085)$, serum triglycerides $(\mathrm{HR}=0.97 ; 95 \% \mathrm{Cl}=0.96-0.98 ; \mathrm{P}<0.0001)$, and $\mathrm{HDL}$ cholesterol $(\mathrm{HR}=0.99 ; 95 \% \mathrm{Cl}=0.99-1.0 ; \mathrm{P}=0.0280)$. Therefore, higher serum HDL cholesterol and higher serum triglycerides were associated with lower mortality in this cohort of outpatients with heart failure.
\end{abstract}

Key words: Heart failure; Prognosis; HDL cholesterol; Chagas' heart disease; Triglycerides

Publication supported by FAPESP.

Received September 6, 2008. Accepted February 11, 2009

\section{Introduction}

Serum lipid and lipoprotein abnormalities have been reported in patients with heart failure (1-5). Low serum total cholesterol is associated with increased mortality in patients with systolic heart failure $(6,7)$. A trend towards a significant relationship between higher serum lipoprotein levels and higher survival rate was suggested (3), but not confirmed (4). Specifically, HDL cholesterol was suggested to have antioxidant, anti-inflammatory and antithrombotic properties that would counteract pro-inflammatory activity in patients with heart failure (8-10).

We measured serum cholesterol, HDL cholesterol, LDL cholesterol, and triglycerides in a cohort of outpatients with heart failure of different etiologies, including Chagas' heart disease, followed from 1991 to 2003. This study was designed to test the hypothesis of an association between serum lipid protein profile and prognosis during a longterm follow-up and if high levels of HDL cholesterol and triglycerides can be protective in these patients.

\section{Patients and Methods}

\section{Patients}

We studied the lipid profile of 833 outpatients with heart failure referred for evaluation and ambulatory treatment of heart failure to the outpatient clinic of a tertiary care reference university public hospital, selected among 1400 referred patients (mean \pm SD left ventricle ejection fraction on echocardiography $33.4 \pm 4.6 \%$; mean left ventricle 
ejection fraction on radioisotopic ventriculography $22.3 \pm$ $8.1 \%$ ) in order to identify potential candidates for heart transplantation.

Inclusion criteria were patients under 75 years of age with a diagnosis of functional class III or IV (NYHA) heart failure due to systolic dysfunction. Exclusion criteria were patients with hypertrophic cardiomyopathy, chronic obstructive pulmonary disease, recent myocardial infarction, and unstable angina. In addition, patients with severe renal or hepatic dysfunction, severe peripheral arterial disease, cerebrovascular disease, insulin-dependent diabetes mellitus with end-organ damage, active infection, coexisting neoplasm, and active peptic ulcer disease were also excluded, as were patients with severe co-morbidities that would make them ineligible for surgery or heart transplantation (11).

\section{Definitions}

Diagnosis of heart failure was made according to the Framingham criteria (12). Diagnosis of the etiology of cardiomyopathy followed previously published criteria (13, 14). Chagas' heart disease was defined as patients with heart failure due to left ventricular systolic dysfunction and positive serologic tests. The association of etiologies such as ischemic and hypertensive cardiomyopathy was considered to be ischemic cardiomyopathy.

Clinical assessment protocol. Patients were referred to the outpatient clinic after diagnosis and stabilization of heart failure. After clinical evaluation, serum cholesterol was evaluated in 833 (59.5\%) patients, HDL cholesterol in 722 (51.5\%), LDL cholesterol in 720 (51.4\%), VLDL cholesterol in $720(51.4 \%)$, and serum triglycerides in 828 (59.1\%).

Medical treatment was further optimized with medical advice regarding everyday living and drug therapy, including captopril and enalapril, furosemide and digoxin available at the Hospital Outpatient Clinic pharmacy. Carvedilol was progressively introduced after 1998. Statin therapy was not routinely administered.

\section{Follow-up}

Follow-up was assessed on the occasion of the last outpatient medical visit or by telephone contact. Patients with missed appointments at the outpatient clinic were actively contacted by means of telephone calls. In addition, the mortality database of the São Paulo City Authority was also scrutinized to determine patient deaths (ProAim Programa de Aprimoramento de Informações de Mortalidade do Município de São Paulo). During the 10-year follow-up period of the study, 80 patients (7\%) underwent the first clinical evaluation and eventually were lost to follow-up.

For the purpose of this study, death was considered to be an event, and heart transplantation and other surgical interventions were defined as censored observations.

\section{Statistical analysis}

After exploratory analysis to identify variables associated with mortality, survival was estimated for each demographic, clinical and laboratory variable in order to identify variables significantly associated with the probability of survival. Unadjusted Kaplan-Meier curves were constructed (15) and survival probabilities were compared using logrank and Breslow methods. For continuous variables, patients were divided into three balanced groups according to the terciles of distribution in order to avoid pre-established categorizations. In the next step, Cox proportional hazards models (16) were fitted to each variable.

The estimated hazard ratios $(\mathrm{HR})$ were then obtained. Because of missing values, the sample considered was not the same for all models. The results are presented as number of cases, events and censored data, P values, HR and $95 \%$ confidence intervals $(95 \% \mathrm{Cl})$.

Ethics. The protocol was approved by the Institution Ethics Committee. Written informed consent was obtained from the patients after identification of potential candidates for heart transplantation.

\section{Results}

The etiology of heart failure was ischemic cardiomyopathy in 171 (20.5\%) patients, Chagas' heart disease in 144 (17.3\%), hypertensive cardiomyopathy in 136 (16.3\%), and other etiologies in 83 (9.9\%). In 299 (35.8\%) patients, heart failure was ascribed to idiopathic dilated cardiomyopathy. Mean patient age was $46.9 \pm 10.6$ years; 655 (78.6\%) were men and $178(21.4 \%)$ were women. Ten patients were younger than 20 years, 58 were 20 to 30 years old, 140 were 30 to 40 years old, 295 were 40 to 50 years old, 69 were 60 to 70 years old, and 3 were 70 to 71 years old

The mean $( \pm S D$ ) duration of symptoms before entry in the study was $49.1 \pm 48.3$ months, the mean duration of follow-up was 658.8 days (median $462, \mathrm{SD}=654.8$, range 3-3584) for patients who died and 1202.8 days (median 1043.5, SD $=959.3$, range 1-4801) for patients who survived the last contact.

Baseline characteristics relative to the etiologies of heart failure are shown in Table 1. Statistically significant differences were observed in relation to duration of the symptoms, age, heart rate, creatinine, body mass index, gender, serum glucose, and death. In the ischemic cardio- 
myopathy group, the patients were older, they had a higher body mass index, lower duration of symptoms, and lower heart rate. In the group of patients with hypertensive cardiomyopathy, we observed fewer males and deaths. There was a significantly lower body mass index in patients with Chagas' cardiomyopathy compared with patients with heart failure of other etiologies $(P=0.0003)$. The other variables compared between Chagas' and non-Chagas' heart disease were not statistically different.

The highest mean values of serum HDL cholesterol, LDL cholesterol and serum triglycerides were observed in patients with hypertensive cardiomyopathy. The lowest mean values of HDL cholesterol were observed in patients with heart failure due to ischemic cardiomyopathy and the lowest mean values of LDL cholesterol and serum triglycerides were observed in patients with heart failure due to all other etiologies. However, there were no statistical differences between the etiologies. Serum glucose was higher than $126 \mathrm{mg} / \mathrm{dL}$ in 137 patients (16.4\%), and between 100 and $126 \mathrm{mg} / \mathrm{dL}$ in 247 patients (29.6\%).

Subsequently, clinical variables and serum lipoprotein variables were tested relative to mortality using a Cox univariate model. The clinical variables associated with mortality were diastolic blood pressure $(P=0.0082)$, serum sodium $(P<0.0001)$, serum leukocyte count $(P<$ $0.0001)$, serum creatinine $(P<0.0001)$, and serum uric

Table 1. Clinical characteristics of the patients relative to the etiology of heart failure.

\begin{tabular}{|c|c|c|c|c|c|c|c|c|c|c|c|}
\hline \multirow[t]{2}{*}{ Variable } & \multicolumn{2}{|c|}{$\begin{array}{l}\text { Chagas' disease } \\
\qquad(N=144)\end{array}$} & \multicolumn{2}{|r|}{$\begin{array}{l}\text { Idiopathic } \\
(N=299)\end{array}$} & \multicolumn{2}{|c|}{$\begin{array}{l}\text { Hypertensive } \\
(N=136)\end{array}$} & \multicolumn{2}{|r|}{$\begin{array}{l}\text { Ischemic } \\
(\mathrm{N}=171)\end{array}$} & \multicolumn{2}{|r|}{$\begin{array}{l}\text { Other } \\
(\mathrm{N}=83)\end{array}$} & \multirow[t]{2}{*}{$\mathrm{P}$} \\
\hline & $\mathrm{N}$ & Mean \pm SD & $\mathrm{N}$ & Mean \pm SD & $\mathrm{N}$ & Mean \pm SD & $\mathrm{N}$ & Mean \pm SD & $\mathrm{N}$ & Mean \pm SD & \\
\hline $\begin{array}{l}\text { Duration of symptoms } \\
\text { (days) }\end{array}$ & 106 & $1486 \pm 1277$ & 228 & $1703 \pm 1666^{* *}$ & 95 & $1238 \pm 1161^{*}$ & 131 & $1183 \pm 1174^{*}$ & 67 & $1567 \pm 1642$ & $0.008^{1}$ \\
\hline Age (years) & 144 & $46.2 \pm 10.5$ & 299 & $45.9 \pm 10.5$ & 136 & $47.7 \pm 0.1$ & 171 & $49.6 \pm 10.2$ & 83 & $45.2 \pm 11.4$ & $0.002^{1}$ \\
\hline \multicolumn{12}{|l|}{ Gender } \\
\hline Male & 114 & & 232 & & 97 & & 147 & & 65 & & $0.040^{2}$ \\
\hline Female & 30 & & 67 & & 39 & & 24 & & 18 & & \\
\hline Deaths & 51 & $(35.4 \%)$ & 114 & $(38.1 \%)$ & 32 & $(23.5 \%)$ & 67 & $(39.2 \%)$ & 27 & $(32.5 \%)$ & $0.031^{2}$ \\
\hline $\begin{array}{l}\text { Body mass index } \\
\qquad\left(\mathrm{kg} / \mathrm{m}^{2}\right)\end{array}$ & 63 & $23.2 \pm 3.5$ & 163 & $24.7 \pm 4.4$ & 83 & $25.2 \pm 4.4$ & 106 & $25.9 \pm 4.7$ & 36 & $23.8 \pm 5.0$ & $0.002^{1}$ \\
\hline $\begin{array}{l}\text { Systolic blood pressure } \\
\qquad(\mathrm{mmHg})\end{array}$ & 47 & $123.6 \pm 23.0$ & 79 & $114.8 \pm 21.4$ & 36 & $114.2 \pm 20.0$ & 47 & $115.6 \pm 19.8$ & 26 & $114.8 \pm 16.7$ & $0.155^{1}$ \\
\hline $\begin{array}{l}\text { Diastolic blood pressure } \\
\qquad(\mathrm{mmHg})\end{array}$ & 47 & $85.3 \pm 20.3$ & 79 & $78.2 \pm 16.8$ & 36 & $82.1 \pm 16.5$ & 48 & $75.0 \pm 21.1$ & 26 & $76.4 \pm 15.9$ & $0.054^{1}$ \\
\hline Heart rate $(\mathrm{bpm})$ & 55 & $79.2 \pm 13.9$ & 126 & $82.5 \pm 15.9$ & 35 & $85.5 \pm 4.4$ & 61 & $79.9 \pm 13.9$ & 30 & $89.6 \pm 13.8$ & $0.007^{1}$ \\
\hline Serum sodium (mmol/L) & 140 & $138.7 \pm 3.6$ & 286 & $138.7 \pm 3.7$ & 130 & $139.2 \pm 3.5$ & 160 & $139.0 \pm 3.5$ & 79 & $138.9 \pm 3.1$ & $0.679^{1}$ \\
\hline Hemoglobin $(\mathrm{g} / \mathrm{dL})$ & 141 & $14.5 \pm 1.6$ & 287 & $14.5 \pm 1.8$ & 135 & $14.6 \pm 1.9$ & 168 & $14.6 \pm 1.6$ & 80 & $14.8 \pm 1.5$ & $0.705^{1}$ \\
\hline Hematocrit (\%) & 141 & $43.6 \pm 4.8$ & 287 & $44.2 \pm 5.7$ & 135 & $44 \pm 5.9$ & 168 & $44.3 \pm 4.8$ & 80 & $44.4 \pm 4.7$ & $0.756^{1}$ \\
\hline Leukocyte count per $\mathrm{mm}^{3}$ & 125 & $7617 \pm 2142$ & 252 & $8048 \pm 2635$ & 116 & $7699 \pm 2205$ & 144 & $8230 \pm 2708$ & 71 & $7831 \pm 2054$ & $0.205^{1}$ \\
\hline Platelets ( x 1000/mm³) & 110 & $226.0 \pm 68.3$ & 221 & $226.8 \pm 74.2$ & 104 & $218.0 \pm 61.7$ & 122 & $215.9 \pm 69.7$ & 60 & $209 \pm 59.6$ & $0.308^{1}$ \\
\hline $\begin{array}{l}\text { Serum cholesterol } \\
\quad(\mathrm{mg} / \mathrm{dL})\end{array}$ & 144 & $194.1 \pm 46.6$ & 299 & $195.6 \pm 46.9$ & 136 & $201.6 \pm 46.4$ & 171 & $199.8 \pm 42.2$ & 83 & $190.6 \pm 51$ & $0.360^{1}$ \\
\hline $\begin{array}{l}\text { Serum triglycerides } \\
\quad(\mathrm{mg} / \mathrm{dL})\end{array}$ & 143 & $137.2 \pm 135.5$ & 296 & $132.4 \pm 94.2$ & 133 & $139.7 \pm 95.6$ & 170 & $138.2 \pm 91.9$ & 83 & $126.4 \pm 75.9$ & $0.856^{1}$ \\
\hline HDL cholesterol (mg/dL) & 129 & $41.8 \pm 13.3$ & 257 & $41.4 \pm 14.8$ & 116 & $42.4 \pm 13.7$ & 144 & $38.8 \pm 12.7$ & 76 & $42.9 \pm 15.6$ & $0.175^{1}$ \\
\hline LDL cholesterol (mg/dL) & 129 & $127.1 \pm 38.9$ & 257 & $128.8 \pm 39$ & 116 & $132.6 \pm 40.5$ & 142 & $131 \pm 37$ & 75 & $123.8 \pm 40.4$ & $0.557^{1}$ \\
\hline VLDL cholesterol (mg/dL) & 129 & $26 \pm 20.6$ & 257 & $25.6 \pm 16.6$ & 116 & $27.3 \pm 17.9$ & 142 & $27.9 \pm 19$ & 76 & $26.5 \pm 16$ & $0.767^{1}$ \\
\hline \multicolumn{12}{|c|}{ Serum glucose $(\mathrm{mg} / \mathrm{dL})$} \\
\hline$<100$ & 72 & & 141 & & 65 & & 79 & & 52 & & \\
\hline $100-126$ & 36 & & 103 & & 35 & & 54 & & 19 & & $0.016^{2}$ \\
\hline$>126$ & 31 & & 38 & & 31 & & 28 & & 9 & & \\
\hline Serum creatinine (mg/dL) & 141 & $1.3 \pm 0.6$ & 293 & $1.2 \pm 0.4$ & 136 & $1.2 \pm 0.4$ & 169 & $1.3 \pm 0.3$ & 82 & $1.2 \pm 0.3$ & $0.026^{1}$ \\
\hline Serum uric acid (mg/dL) & 90 & $8.1 \pm 2.2$ & 184 & $8.1 \pm 2.5$ & 79 & $7.9 \pm 2.3$ & 91 & $8.1 \pm 2.9$ & 50 & $8.6 \pm 2.6$ & $0.652^{1}$ \\
\hline
\end{tabular}

Data are reported as number of patients and means \pm SD. Measurements were made anytime during the transplant evaluation. Patients were followed for $905+846$ days. $P$ values in bold indicate statistically significant differences. ${ }^{1}$ ANOVA and ${ }^{2}$ chi-square test were used for statistical analysis. 
acid $(P<0.0001)$ (Table 2$)$. Lipid profile variables significantly associated with mortality were serum cholesterol $(P$ $<0.0001)$, serum triglycerides $(P=0.045)$, HDL cholesterol $(P<0.0001)$, and LDL cholesterol $(P=0.0075)$ (Table 2$)$.

Lipid profile variables, gender, age, and etiology were submitted to multivariate analysis using a Cox proportional hazards model. The associations that remained significantly associated with mortality were HDL cholesterol $(P=$
$0.0280)$, triglycerides $(P<0.0001)$, VLDL cholesterol $(P=$ $0.0074)$, age $(P=0.0074)$, gender $(P=0.0040)$, and idiopathic dilated cardiomyopathy relative to hypertensive cardiomyopathy $(P=0.0085)$, which was the etiology associated with the lowest mortality (Table 3 ).

For each $1 \mathrm{mg} / \mathrm{dL}$ increase of HDL cholesterol there was a $1 \%$ decrease in mortality, and for each $1 \mathrm{mg} / \mathrm{dL}$ increase of triglycerides there was a $4 \%$ decrease in mortality.

\section{Discussion}

Table 2. Univariate survival analysis.

\begin{tabular}{lcrrr}
\hline Univariate analysis & $\begin{array}{c}\text { Number } \\
\text { of cases }\end{array}$ & P & $\begin{array}{c}\text { Hazard } \\
\text { ratio }\end{array}$ & $95 \% \mathrm{Cl}$ \\
\hline Duration of symptoms (days) & 625 & 0.3100 & 1.00 & $(1.00-1.00)$ \\
Age (years) & 829 & 0.0360 & 1.01 & $(1.00-1.02)$ \\
Body mass index $\left(\mathrm{kg} / \mathrm{m}^{2}\right)$ & 449 & 0.6500 & 0.99 & $(0.96-1.02)$ \\
Systolic blood pressure $(\mathrm{mmHg})$ & 233 & 0.9500 & 1.00 & $(0.99-1.01)$ \\
Diastolic blood pressure $(\mathrm{mmHg})$ & 234 & 0.1600 & 0.99 & $(0.97-1.00)$ \\
Heart rate $(\mathrm{bpm})$ & 307 & 0.8100 & 1.00 & $(0.99-1.01)$ \\
Serum sodium $(\mathrm{mEq} / \mathrm{L})$ & 791 & $<0.0001$ & 0.92 & $(0.88-0.95)$ \\
Hemoglobin $(\mathrm{g} / \mathrm{dL})$ & 807 & 0.8700 & 1.00 & $(0.94-1.08)$ \\
Hematocrit $(\%)$ & 807 & 0.0510 & 1.02 & $(1.00-1.05)$ \\
Leukocytes $\left(/ \mathrm{mm}{ }^{3}\right)$ & 704 & $<0.0001$ & 1.00 & $(1.00-1.00)$ \\
Platelets $\left(1000 / \mathrm{mm}{ }^{3}\right)$ & 616 & 0.7800 & 1.00 & $(0.99-1.00)$ \\
Serum cholesterol $(\mathrm{mg} / \mathrm{dL})$ & 829 & $<0.0001$ & 0.99 & $(0.99-0.99)$ \\
Serum triglycerides $(\mathrm{mg} / \mathrm{dL})$ & 821 & 0.0450 & 0.99 & $(0.99-1.00)$ \\
HDL cholesterol $(\mathrm{mg} / \mathrm{dL})$ & 719 & $<0.0001$ & 0.97 & $(0.96-0.98)$ \\
LDL cholesterol $(\mathrm{mg} / \mathrm{dL})$ & 716 & 0.0075 & 0.99 & $(0.99-0.99)$ \\
VLDL cholesterol $(\mathrm{mg} / \mathrm{dL})$ & 717 & 0.0550 & 0.99 & $(0.98-1.00)$ \\
Serum glucose $(\mathrm{mg} / \mathrm{dL})$ & 789 & 0.5700 & 1.00 & $(0.99-1.00)$ \\
Serum creatinine $(\mathrm{mg} / \mathrm{dL})$ & 817 & $<0.0001$ & 1.59 & $(1.32-1.92)$ \\
Serum uric acid $(\mathrm{mg} / \mathrm{dL})$ & 490 & 0.0001 & 1.11 & $(1.05-1.18)$ \\
\hline
\end{tabular}

After exploratory analysis, clinical variables and serum lipoprotein variables were analyzed using univariate Cox proportional hazards model.

Table 3. Multivariate survival analysis.

\begin{tabular}{lrrrr}
\hline Multivariate analysis & $\begin{array}{c}\text { Coefficient } \\
\text { (beta) }\end{array}$ & $P$ & $\begin{array}{c}\text { Hazard } \\
\text { ratio }\end{array}$ & $95 \% \mathrm{Cl}$ \\
\hline Age (years) & 0.0170 & 0.0074 & 1.02 & $(1.00-1.03)$ \\
Gender (female/male) & 0.5727 & 0.0040 & 1.77 & $(1.20-2.62)$ \\
Chagas' disease/hypertensive & 0.3993 & 0.1200 & 1.49 & $(0.90-2.45)$ \\
Idiopathic/hypertensive & 0.5950 & 0.0085 & 1.81 & $(1.16-2.82)$ \\
Ischemic/hypertensive & 0.4292 & 0.0780 & 1.54 & $(0.95-2.48)$ \\
Others/hypertensive & 0.2469 & 0.4000 & 1.28 & $(0.72-2.26)$ \\
Serum cholesterol (mg/dL) & -0.0034 & 0.0930 & 0.99 & $(0.99-1.00)$ \\
Serum triglycerides (mg/dL) & -0.0334 & $<0.0001$ & 0.97 & $(0.95-0.98)$ \\
HDL cholesterol $(\mathrm{mg} / \mathrm{dL})$ & -0.0043 & 0.0280 & 0.99 & $(0.99-1.00)$ \\
LDL cholesterol $(\mathrm{mg} / \mathrm{dL})$ & -0.0003 & 0.9700 & 1.00 & $(0.98-1.02)$ \\
VLDL cholesterol $(\mathrm{mg} / \mathrm{dL})$ & 0.0170 & 0.0074 & 1.01 & $(1.00-1.03)$ \\
\hline
\end{tabular}

Gender, age, and etiology were fitted and lipid profile variables were analyzed using multivariate Cox proportional hazards model.
Our data demonstrated that higher serum HDL cholesterol and triglycerides were associated with lower mortality in a cohort of outpatients with symptomatic heart failure of different etiologies. Previous reports in the literature with small samples, a predominance of patients with ischemic etiologies of heart disease and different statistical analysis of serum cholesterol and lipoproteins did not detect a significant relationship between HDL cholesterol and survival rate of patients with heart failure including Chagas' heart disease $(3,4,6,7,17)$.

In fact, a protective role for HDL cholesterol in patients with heart failure observed in our patients may be explained on the basis of the endotoxin-lipoprotein hypothesis, which suggests that serum lipoproteins modulate inflammatory immune function (6) and that HDL cholesterol has antioxidant, anti-inflammatory and anti-thrombotic properties $(10,18)$.

The hypothesis that HDL cholesterol can be a marker of coronary artery disease might influence our findings was evaluated by adjusting etiologies and testing for interaction between covariates such as HDL cholesterol relative to ischemic heart disease. Higher mean serum HDL cholesterol was observed in patients with hypertensive cardiomyopathy and in patients with heart failure grouped as other etiologies (valvular cardiomyopathy, alcoholic cardiomyopathy, peripartum cardiomyopathy, myocarditis, adriamycin toxicity, endomyocardial fibrosis, late postoperative aortic dissection). The lowest mean serum HDL cholesterol was detected in patients with heart failure due to ischemic cardiomyopathy. Firstorder interactions of etiology with the other covariates including HDL cholesterol were tested in the final model and revealed a non-significant interaction at the $5 \%$ level of significance $(P=$ 0.2512). 
By contrast, in this study, serum cholesterol and LDL cholesterol did not remain significantly associated with mortality after multivariate analysis, as reported recently in a study of 422 patients with heart failure due to idiopathic dilated cardiomyopathy (17). The statistical treatment of serum cholesterol and lipoproteins as continuous variables in the present study might be responsible for this result. On the other hand, in previous experiences, serum cholesterol and LDL cholesterol were evaluated in quintiles (3), or serum cholesterol was evaluated in quartiles, or with a cut-off value of $5.2 \mathrm{mmol} / \mathrm{L}$ (4) or in tertiles (17).

We also demonstrated a statistically significant relationship between serum triglycerides and mortality, as previously reported $(3,4,17)$. Further, we did not observe a statistically significant association between body mass index and mortality. This finding may be related to the fact that few patients with cardiac cachexia were included in the present study.

We have previously addressed the contribution of left ventricle ejection fraction as evaluated by echocardiography to prognosis (19). In the present study sample, we were not able to demonstrate that ejection fraction, estimated by echocardiography, predicts a less favorable outcome. Serum sodium level in this study sample was a significant prognostic factor in the univariate analyses, but this significance was lost in multivariate analysis.

\section{References}

1. Rauchhaus M, Koloczek V, Volk H, Kemp M, Niebauer J, Francis DP, et al. Inflammatory cytokines and the possible immunological role for lipoproteins in chronic heart failure. Int J Cardiol 2000; 76: 125-133.

2. Sharma R, Anker SD. Immune and neurohormonal pathways in chronic heart failure. Congest Heart Fail 2002; 8: 23-8, 48 .

3. Horwich TB, Hamilton MA, Maclellan WR, Fonarow GC. Low serum total cholesterol is associated with marked increase in mortality in advanced heart failure. J Card Fail 2002; 8: 216-224.

4. Rauchhaus M, Clark AL, Doehner W, Davos C, Bolger A, Sharma $\mathrm{R}$, et al. The relationship between cholesterol and survival in patients with chronic heart failure. J Am Coll Cardiol 2003; 42: 1933-1940.

5. Jessup M, Brozena S. Heart failure. N Engl J Med 2003; 348: 2007-2018.

6. Afsarmanesh N, Horwich TB, Fonarow GC. Total cholesterol levels and mortality risk in nonischemic systolic heart failure. Am Heart J 2006; 152: 1077-1083.

7. May HT, Muhlestein JB, Carlquist JF, Horne BD, Bair TL, Campbell BA, et al. Relation of serum total cholesterol, Creactive protein levels, and statin therapy to survival in heart

failure. Am J Cardiol 2006; 98: 653-658.

8. Rauchhaus M, Coats AJ, Anker SD. The endotoxin-lipoprotein hypothesis. Lancet 2000; 356: 930-933.

9. Anker SD, Sharma R. The syndrome of cardiac cachexia. Int J Cardiol 2002; 85: 51-66.

10. Ansell BJ, Watson KE, Fogelman AM, Navab M, Fonarow GC. High-density lipoprotein function recent advances. $J$ Am Coll Cardiol 2005; 46: 1792-1798.

11. Costanzo MR, Augustine S, Bourge R, Bristow M, O'Connell JB, Driscoll D, et al. Selection and treatment of candidates for heart transplantation. A statement for health professionals from the Committee on Heart Failure and Cardiac Transplantation of the Council on Clinical Cardiology, American Heart Association. Circulation 1995; 92: 3593-3612.

12. McKee PA, Castelli WP, McNamara PM, Kannel WB. The natural history of congestive heart failure: the Framingham study. N Engl J Med 1971; 285: 1441-1446.

13. Report of the WHO/ISFC task force on the definition and classification of cardiomyopathies. Br Heart J 1980; 44: 672-673.

14. Richardson P, McKenna W, Bristow M, Maisch B, Mautner B, O'Connell J, et al. Report of the 1995 World Health Organization/International Society and Federation of Cardi- 
ology Task Force on the Definition and Classification of Cardiomyopathies. Circulation 1996; 93: 841-842.

15. Kaplan EL, Meier P. Nonparametric estimation from incomplete observations. J Am Stat Assoc 1958; 53: 457-481.

16. Cox DR. Regression models and life tables. J R Stat Soc $B$ 1968; 30: 248-275.

17. Christ M, Klima T, Grimm W, Mueller HH, Maisch B. Prognostic significance of serum cholesterol levels in patients with idiopathic dilated cardiomyopathy. Eur Heart J 2006; 27: 691-699.

18. Barter PJ, Nicholls S, Rye KA, Anantharamaiah GM, Navab M, Fogelman AM. Antiinflammatory properties of HDL. Circ
Res 2004; 95: 764-772.

19. Freitas HF, Chizzola PR, Paes AT, Lima AC, Mansur AJ. Risk stratification in a Brazilian hospital-based cohort of 1220 outpatients with heart failure: role of Chagas' heart disease. Int J Cardiol 2005; 102: 239-247.

20. Barter PJ, Caulfield M, Eriksson M, Grundy SM, Kastelein $\mathrm{JJ}$, Komajda M, et al. Effects of torcetrapib in patients at high risk for coronary events. N Engl J Med 2007; 357: 2109-2122.

21. Kontush A, Guerin M, Chapman MJ. Spotlight on HDLraising therapies: insights from the torcetrapib trials. Nat Clin Pract Cardiovasc Med 2008; 5: 329-336. 